\title{
Emerging school-level education policy under National 2008-9
}

\section{MARTIN THRUPP}

\section{Abstract}

This article discusses school level education policy developments over 2009, during National's first year in office. National was elected amidst a growing sense of recession and quickly made cuts to a range of programmes, claiming these were necessary to rein in government spending. However there was a hollow ring to these claims given the nature of what was cut and given new spending on private schools. A stronger privatisation agenda was signalled in other areas as well and in its first year National also introduced National Standards, a nationwide form of assessment for primary and intermediate school children. This article discusses these developments and their contestation by some in the sector. It concludes that if the contested ideology of neoliberalism comes to further dominate New Zealand education policy in the next few years, research could have an important role to play in providing some light amidst the heat of reform. However, New Zealand's capacity to undertake research into the impact of education policy is becoming quite limited. This is making it increasingly important to tap into academic analyses of neo-liberal policies in other national settings where research and scholarship is often better funded and more able to be searching than its New Zealand counterpart.

\section{Introduction}

7 his article reviews key developments in school-level education policy during National's first year in government, November

2008 to November 2009. ${ }^{1}$ The new government, led by John Key, could be predicted to bring a neo-liberal emphasis to education policy for at least three reasons. First, there was National's previous record in education in the 1990s which had seen bulk-funding of teacher salaries, less regulated school enrolment policies, and a heavy emphasis on external accountability through the Education Review Office (see Thrupp, 1999). Second, although the intervening nine years of Labour administration had involved some turning away from neo-liberalism, this had been limited. A recent collection of papers on education policy over the last decade illustrates that under Helen Clark 
Labour did not so much undo the neoliberal project in New Zealand education as take some of the rough edges off it: producing neoliberalism with a social conscience (Thrupp \& Irwin, 2010). ${ }^{2}$ Third, National also now had two new support parties to keep on side, one of which - ACT - was clearly neo-liberal. The same could not be said of the Māori Party; however, since Māori political interests do not readily line up along a left/right axis, the potential for alignment turned out to be greater than perhaps was first apparent. 'Choice' policies had in some ways worked for Māori in the 1990s, allowing the establishment of kura kaupapa Māori as an alternative form of Māori education. The election manifesto of the Māori Party, although not overtly neo-liberal, included elements which could chime with a neo-liberal emphasis on educational choice and competition. ${ }^{3}$

Despite all this, it was uncertain to what extent National would return to the agenda of the 1990s. National's politics and politicians had clearly shifted somewhat during the Labour interregnum. As well, whereas Labour had ruled during a period of prosperity and was able to increase its funding of Vote Education by $80 \%$ (Office of Hon. Chris Carter, 2008), National was elected amidst a growing sense of national and global recession. On the face of it, a government of any stripe would have faced some tough decisions in education following the election, and certainly a feature of National's first year was some significant cuts to professional development and school staffing budgets which were explained as necessary to rein in government finances. Yet National undertook new spending in education as well. It is necessary to look at the detail of both the cuts and the new spending to assess what they represent. Finally it would often be unrealistic in any case to assume a very obvious correspondence between political ideology and policy. As Levin (2001) points out, policymaking is more contingent and ambiguous than this: "political decisions are shaped by many considerations, including the requirements of staying in office and the vicissitudes of the moment as well as the beliefs and commitments of policymakers and their advisors" (p. 22). Indeed, Ball (1998) describes national policy making as:

...inevitably a process of bricolage: a matter of borrowing and copying bits and pieces of ideas from elsewhere, drawing upon and amending locally tried and tested approaches, cannibalising theories, research, trends and fashions and not infrequently flailing around for anything at all that looks as though it might work. (p. 126) 
Taking all the above into account, this article critically reviews the school-level education policy developments in National's first year and notes a decline in consensus in the educational sector as it contested some of the new directions. The introduction of 'National Standards', a nationwide form of assessment for primary and intermediate school children, was the most important initiative launched over this period, bringing new performative pressures in primary education. There were also new moves towards privatisation and a significant extension of the Te Kotahitanga programme. Privatisation is clearly a neo-liberal aspiration but what National's support for Te Kotahitanga represents is not so clear-cut. The article concludes that National's first year did move education policy in a more clearly neo-liberal direction and made school level education policy in New Zealand more contested than it had been for a decade. It is suggested that given this context, it is becoming increasingly important to tap into academic analyses of neo-liberal policy in other national settings where research and scholarship are often able to be more searching than in New Zealand.

\section{The election and its aftermath}

Both National and Labour only released their full school sector education policies the week before the election on 8 November 2008. The response from the sector was that they were short on detail ("Nuts and bolts", 2008). Gerritsen (2008) characterised the policies as offering only "a handful of simple choices for education minded voters: "increased funding for private schools or not and a move towards national testing of primary school children or not" (p. 1). After the election, Anne Tolley became Minister of Education, Minister responsible for ERO (Education Review Office), and Minister for Tertiary Education. The Confidence and Supply agreements National signed with the ACT Party and the Māori Party were reflected in ACT MP Heather Roy and Māori Party MP Peter Sharples both becoming Associate Ministers of Education. National's agreement with ACT made some concessions to ACT's educational choice agenda (discussed further below) but the Māori Party's agreement with National did not go into specific policies in the area of education.

One of the first actions of the new Government was to remove a clause in the National Administration Guideline 5 requiring healthy 
food to be sold on school premises. National also quickly threw out a bill before the House, the Education Amendment Bill (no 3) which was legislation Labour would have used as part of its 'Schools Plus' initiative to prevent 15 year-olds from leaving school. Both actions symbolised a determination to end what was seen as Labour's 'nannying' over-intervention in schools. Indeed, Tolley described the 'Schools Plus' policy as reflecting "a socialist reaching out to claw back control from schools and communities and to put in place central control over how our schools are run" (quoted in Harris, 2008, p. 1). In the case of the healthy food clause, the Minister's justification was that " $[\mathrm{t}]$ his government trusts Boards of Trustees who are, after all, parents of the children who are attending the schools, to make sensible decisions and responsible decisions, about the types of food which are served to their children, at their schools" (Tolley, 2009). The extent to which National was determined to chart a new direction at any cost was later highlighted when Tolley admitted in Parliament (29 April 2009) that she had removed the healthy food clause against the advice of her own officials and without seeking any advice from Ministry of Health officials.

\section{Private schools and privatisation}

It was apparent before the election that National would be offering more support for private schools ("Key plans", 2007). This support, along with a limited number of scholarships to private schools for children from low income families, came to pass during National's first year which was also marked by debate over the integration of private schools into the state system.

The 2009 budget allocated an extra \$35million over four years to independent schools, whose subsidy from the state had been frozen at $\$ 42$ million since 2000. This was a controversial development given the recessionary context. For instance Peter Gall, President of the Secondary Principals' Association, was quoted as saying that some excellent programmes had been cut in the state sector while private schools benefited (Hartevelt, 2009a). Minto (2009a) pointed out that independent schools educate fewer than 4 per cent of children but gained \$35 million in additional funding, whereas the other 96 per cent in state schools received just $\$ 320$ million extra in the Budget: "A simple bit of maths shows the Budget delivered around three times the 
amount of additional funding to private schools compared with public schools".

Tolley was unwilling to be drawn on why the funding for independent schools had gone ahead when other promises had been shelved because of the recession ("Government accused", 2009). Nevertheless a number of arguments were employed to justify it. Prime Minister John Key argued that the cap on independent school funding had pushed up fees and made these schools increasingly elitist so that an increase in funding would help make independent schools more affordable for many struggling parents ("Key plans", 2007). On the other hand Harris (2008b) found independent school leaders saying that Labour's funding cap in 2000 meant that the extra funding would all be needed for just running their schools, rather than allowing any reduction in school fees. More ideological arguments were employed by Heather Roy (2009) when, addressing the CEOs of independent schools, she suggested that "parents who send their children to an independent school are helping to alleviate the burden on the State education system" and that "parents of [independent school] pupils pay for their children's education twice: once through their taxes, and again when they cover the cost of choosing the right school for their child".

Roy's (2009) arguments were made in the context of independent school bids for integration, another issue that came to the fore in 2009 as the recession made it more difficult for parents to afford to pay independent school fees and their rolls were expected to decline (Pepperell, 2009; Smith, 2009a). These pressures led some independent schools to bid for integration, in some cases with serious intent, others probably only as a means of drawing attention to their financial problems. In March, the headmaster of Wanganui Collegiate, Tim Wilbur, told Radio New Zealand that he had written to the government to ask about the possibility of Wanganui Collegiate becoming an integrated school because of fears for its financial viability. However, this action was criticised by the Post-Primary Teachers' Association as taking funding away from struggling state schools ("Govt should not bail out", 2009). This in turn led Roy to present the arguments above. However, Minto (2009b) responded that actually it was parents whose children attend state schools who were paying twice, not those attending independent schools: "Once through taxes for their children's local school and then secondly to pay for 
private and some integrated schools to maintain their socially or religiously-cleansed environments for the children of the wealthy". He further argued that the problem with independent schools integrating lay in the fact that they did not have to give up their exclusivity:

A private school which integrates with the public school system has its teacher
salaries and day to day operating expenses paid by the government but it retains
ownership of the school land and buildings and retains its "special character". In
theory the school largely trades its right to charge private school fees and its
right to pick and choose students for government payment of everything except
the upkeep of school buildings and new building developments. In practice
however many integrated schools have maintained their exclusivity by charging
many thousands of dollars in building levies so that unlike state schools they are
not open to enrolment by anyone but wealthy families able to pay. They
essentially remain private schools but with full government funding for day-to-
day operations. (Minto, 2009b)

Independent schools received further support with the announcement in September 2009 of 'Aspire' scholarships to provide children from lower income families an 'enhanced educational opportunity' by attending private schools, The scholarships would be for families with an annual income of $\$ 65,000$ or less, and a combined net worth of less than $\$ 150,000$. Up to $\$ 15,000$ per year in fees and $\$ 1,500$ in course costs will be paid. There would be 150 places available in 2010 rising to 250 per year by 2012. Gordon (2009a) noted the similarities of the Aspire scholarships to the Targeted Individual Entitlement scheme run by National in the 1990s and that there had been a number of serious problems with that scheme (see also Smith \& Gaffney, 1997). For example, Smith and Gaffney found that students had been teased or bullied, families faced financial hardship trying to provide for non-funded activities, only one child per family could attend so younger siblings were precluded from also attending (thereby generating family tensions), and since few private schools participated in the scheme then parental choice was very limited anyway. The Aspire scheme looked likely to be beset with many of the same problems. Again, the number of places offered to the 'deserving poor' were very few (and, slightly unexpectedly, determined by ballot if oversubscribed), there were areas which are not served by private schools so boarding would often be necessary (no private secondary schools in Otago or Southland for instance, see Lewis, 2009), and none of the Māori boarding schools were included as they are not private schools. 
Another move towards privatisation had been signalled prior to the election when it was reported that National was considering using private developers to build and own state schools (Trevett, 2007). Public-private partnerships came a step closer in July 2009 when it was announced that the New Zealand Superannuation Fund had put up to $\$ 100$ million into a public-private partnership (PPP) fund investing in New Zealand infrastructure such as schools, hospitals and housing. The Public Infrastructure Partnership fund was being set up by privately-owned infrastructure manager Morrison \& Co ("Publicprivate infrastructure", 2009); the facilities would be handed back to public ownership after "two to three decades" of charging an annual fee. It was reported in September that the fund would start with up to $\$ 500$ million but was eventually intended to stand at $\$ 1-1.5$ billion (Gibson, 2009). Gibson reported property director Peter Coman saying that education facilities were a top priority: "The focus will be on education, corrections, health, transport-related infrastructure, defence force accommodation, local government water infrastructure and community facilities". Coman also described the New Zealand Superannuation Fund as the 'key investor' which was significant given heavy government sponsorship of public private partners in other policy settings, e.g., the UK. The scheme would work as follows:

The need for a new prison or school would result in a project company being established. The Government would pay that company for delivering the building. No payments would be made until the school or prison was finished. The fund's role would be to select contractors to design, build and maintain the school or prison which would then be transferred to the Government. (Gibson, 2009)

Public private partnerships for New Zealand have been criticised, drawing on international experience (e.g., Rudman, 2008), and for New Zealand education more specifically (Hunt, 2009). Nevertheless, National is clearly keen on PPPs ("Public Private Partnerships", 2009) and there is also a well-organised business lobby group to promote PPPs, the New Zealand Council for Infrastructure Development (NZCID). By October 2009, Aorangi, a Christchurch school facing closure rather than rebuilding, was being thought of as a potential candidate for a PPP with Ngai Tahu as the business partner (Todd, 2009).

There were other developments with potential to contribute to privatisation during 2009. One was the tabling of an Education 
Amendment Bill in April that would have allowed 'body corporates' to step in as Commissioners for 'failing boards'. While the Minister claimed that the intent of the wording was to allow boards from other schools to take over 'failing boards', it became clear that the 'body corporate' phrase could be used to allow companies and other organisations to be appointed ("Corporations running schools", 2009). Also signalled was a possible return to bulk funding with informal discussion about moving guidance counsellors from schools' staffing budgets to their operations budget. This was part of the Ministry of Education grappling with how to cut $50 \mathrm{~m}$ per year from schools' staffing (Hartevelt, 2009b, see also below).

Finally, there was continuing advocacy work being done by ACT. The National-Act Confidence and Supply Agreement (2008), signed on 16 November 2008, contained the following statement:

\begin{abstract}
National has stated that it will "work, over time, to increase the education choices available to parents and pupils so families have more freedom to select schooling options that best meet the individual needs of their children." ACT also favours greater choice and competition in education. In pursuit of these goals, National and ACT have agreed to set up an inter-party working group, which shall be resourced as necessary to consider and report on policy options relating to the funding and regulation of schools that will increase parental choice and school autonomy.
\end{abstract}

The working party became active but did not report during National's first year. Nevertheless Heather Roy often advocated a privatisation agenda which includes more 'choice', funding for the private sector, deregulation and contracting out (e.g., Roy, 2009). What was entirely missing from this advocacy, however, was any recognition that education is a positional good. As Gordon (2009b) put it, Roy did not acknowledge the problem that in education "the choosers are also part of the commodity - that is, schools are attractive or not depending primarily on who goes to them" (p. 7).

In contrast to all the other activity around privatisation, there was relatively little discussion of school zoning in relation to choice. By April 2009, Auckland's most sought-after state schools were lobbying the government to bring in the policy of allowing them to accept the children of former students who live outside their zone (Smith, 2009b), and some commentators were using the opportunity to express their support for a revision. A New Zealand Herald editorial suggested that National voters couldn't expect both the assurance of typically being 'in zone' and an extensive relaxation of zoning. It argued that 
while electoral pressures would probably scupper any plans to extensively relax the zoning laws, National should be supporting the principle of choice and the market competition between schools it would create ("Principle must triumph", 2009). Another Herald columnist expressed concern that 'selection by mortgage' had had the effect of reducing the number of Māori and Pasifika students at Auckland Boys' Grammar (although the period of decline cited was since 1993, not just since 2000 when Labour's zoning laws took effect, Roughan, 2009). This concern chimed with the arguments of the Maxim Institute, a neo-conservative lobby group which had argued that removing zoning would make access to schools fairer for low socio-economic families on the assumption that most such families would benefit from increased 'choice' (Thomas, 2007).

\section{Funding cuts}

The 2009 Budget released on 28 May 2009 required some trimming of Ministry of Education and ERO budgets and wholesale cuts to some programmes and initiatives. While the most controversial of these was an $80 \%$ cut in funding for Adult and Community Education courses, there were also some school programmes cut including Education for Sustainability (under which the Enviroschools programme was funded), the Artists in Schools programme, E-learning fellowships and professional development in the areas of gifted and talented and health education. Also cut were the contestable Extending High Standards across Schools initiative and the Innovations Pool for Students At Risk. More ominous, especially against the background of a demographic bulge in school populations, was the intention to save about $\$ 50$ million per year or $1.5 \%$ per year on teachers' salaries. By September it was revealed that the Government planned to lay off the equivalent of 772 full-time teachers, but backed down days before the 1106 affected schools were to be told. The cuts involved a reversal of lower teacher-pupil ratios for new-entrant classes with the 1:15 ratio started in 2009 being scrapped and returned to the previous 1:18 (Hartevelt, 2009c). Nevertheless, the cuts seemed only to be delayed as the Ministry looked for other means to trim the school staffing budget by $\$ 50$ million.

On the other side of the ledger, there was the new funding for private schools already noted, fresh investment in some truancy and behaviour initiatives, and schools' operating budgets were increased 
by $1.95 \%$. Also particularly noteworthy were the extension of Te Kotahitanga, and funding for the introduction of National Standards. These latter two developments are discussed further below.

\section{Te Kotahitanga}

The 2009 budget saw additional funding of almost \$20 million over four years to allow expansion of the Te Kotahitanga project into 15 new secondary schools and for the design and delivery of $\mathrm{Te}$ Kotahitanga-based professional leadership programmes for up to 100 principals of secondary schools each year. The Te Kotahitanga programme began in 2001 and aims to support Māori students in regular secondary schools by turning teachers away from 'deficit' discourses and positionings towards more agentic ones centred on classroom relationships. Te Kotahitanga was noteworthy for being expanded not only in a time of fiscal restraint but also in advance of a three-year evaluation of its impact on the goal of raising Māori student achievement. This evaluation had, in turn, followed large claims for its impact ${ }^{5}$ and a critical report commissioned by the PPTA (Openshaw, 2007).

National's support for Te Kotahitanga, an initiative developed under Labour, could be seen as important for its relationship with the Māori Party which in its election manifesto (Māori Party, 2008) had pledged support for professional development for teachers, "particularly in cultural competency. But as the Māori Party is often more interested in developing Kaupapa Māori forms of education (e.g., "Māori students", 2010; Sharples, 2010), it is just as likely that National's support for Te Kotahitanga lies in the general political malleability of what is essentially a school effectiveness initiative. That is, Te Kotahitanga would appeal to any government that wanted to put responsibility for student failure on the shoulders of schools and teachers. For instance, by strongly dismissing sociological arguments about the impact of socio-economic status on Māori achievement as "deficit theorizing" (Bishop, Berryman, Tiakiwai \& Richardson, 2003, p. 95; Bishop, 2005), Te Kotahitanga chimes with the view expressed by Anne Tolley that poverty is too often used as an excuse for underachievement. ${ }^{6}$ Indeed there is overt ideological work being done here as the project seeks to actively prevent teachers from thinking about socio-economic issues through defining sociological 
perspectives as deficit theories and then requiring teachers to "positively and vehemently reject deficit theorising as a means of explaining Māori students' educational achievement levels". ${ }^{7}$ Black (2008) has described this Te Kotahitanga requirement as a "vaguely Orwellian approach - acting as though all the other influences in a child's life do not exist"' (p. 14).

One problem with screening out socio-economic issues is that there is evidence that low decile schools make the best progress when they fully acknowledge and respond to the cultural backgrounds from which their students come (Smyth \& McInerney, 2007). Culture is of course not just a matter of ethnicity, it also has social class dimensions and to highlight the former and seek to ignore the latter is counterproductive. Telling teachers they must ignore socioeconomic issues also removes any resort to the contextual claim that they otherwise might fall back on when faced by the politics of blame. For instance in a situation where a government agency is unfavourably comparing the performance of schools dominated by lowsocioeconomic students with more middle class schools, the teachers in the former would be unable to reject culpability for student failure even where this culpability was patently unrealistic. Hence the paradox of Te Kotahitanga is that its enthusiasm for the power of teaching could help to support a situation where 'poorly performing' schools are publicly castigated, find it difficult to recruit teachers, and could even be shut down. Many of those schools will invariably be low-decile schools and many will have large numbers of Māori students. To the extent that teachers serve communities, including remote and disadvantaged communities, support for the politics of blame can be expected to have wider consequences than for teachers alone.

\section{National Standards}

On 13 December 2008 the Education (National Standards) Amendment Bill was passed. The National Party had long argued for more testing in schools, having raised proposals for national testing in 1997, 1999 and 2005. In April 2007 the then Opposition Leader, John Key, announced the intention to introduce National Standards tied to expected levels of achievement for all students by the end of each of Years 1-8 in mathematics, reading and writing. National Standards are not measured by a single high-stake test as is the typical of national testing in other 
countries. Rather, they are standards against which a range of tests, including those previously used for formative achievement, can be benchmarked. The shift from National testing to National Standards seems to have been a response to advice from University of Auckland academic Professor John Hattie and perhaps also in anticipation of opposition to national testing from the school sector. However, the difference was not enough to prevent growing concern amongst primary teachers, principals and others that National Standards would lead to league tables, an increasingly narrow curriculum, and the various other perverse consequences for schools and students evidenced under national testing regimes elsewhere (Thrupp \& Hursh, 2006).

The reluctance of the Minister to provide clear reasons for introducing National Standards or to acknowledge possible problems with them did little to allay such concern. There was an obvious mismatch between National Standards for all New Zealand children and the claim that National Standards were most needed to address the problem of the $20 \%$ of children, especially Māori and Pasifika, who made up New Zealand's so-called 'long tail of underachievement' as the latter would imply a more targeted approach. Some of the Minister's statements suggested the Government was operating with simplistic notions of poorly performing teachers needing to be made more accountable. The Minister also dismissed arguments based on the experience of national testing in other countries on the grounds that National Standards would allow for a range of tests rather than a single one. She offered few assurances about the way the National Standards would be used by government or the media. Indeed, until the opposition to national standards became too obvious to ignore, Tolley argued that the sector was largely supportive. This stance ignored well-publicised research evidence to the contrary provided as early as October 2008 (Schagen \& Hipkins, 2008).

Further concerns revolved around how National Standards were being implemented at speed and without effective consultation. The 13 December Bill had been passed under urgency, allowing it to bypass the Education and Science Select Committee where the merits of National Standards could have been debated. The formal consultation period from 18 May to 3 July saw meetings in the regions as well as main centres and there was the opportunity to make submissions with almost 5000 of these analysed and reported by 
researchers at NZCER. There were two problems with the consultation. The first was that both the consultation meetings and the forms provided for making submissions structured the responses to be about the draft National Standards provided, not more broadly about the concept of national standards or whether New Zealand needed them. As one correspondent to the Dominion Post complained:

This government hasn't played by the rules of our democratic society. The parent consultation, which I attended, stated quite simply that National Standards were coming because the government had already changed the law. Now do you want the Plunket graph [approach to reporting achievement results] or the other one? Sir Humphrey Appleby (of Yes Minister fame) would have been proud of this government and its consultation processes. ${ }^{8}$

A second problem involved the political spin put around the findings of the consultation. Repeating the pattern of not acknowledging concerns about National Standards, a press release from Minister Tolley's office on 20 September claimed that "Consultation feedback shows strong support from parents for National Standards" ("Parents support National Standards", 2009). In fact the report analysing consultation feedback showed considerable diffidence amongst parents with $38 \%$ of parents making negative comments about the National Standards system and only 14\% making positive comments (Wylie, Hodgen \& Darr, 2009).

The consultation, such as it was, did little to dampen the concerns of the sector; indeed, it was towards the end of the consultation period that the NZEI (New Zealand Education Institute) and NZPF (New Zealand Principals' Federation), having consulted extensively with their members, firmed up their opposition to National Standards and more particularly their potential for league tables. In the case of the NZEI this was done at the end of June through a press release which called on government to push out the timeline and said schools would actively oppose any centralised reporting of the standards data (Anger over National Standards consultation, NZEI, 2009). In early July the NZPF conference was used as a platform to voice primary principals' opposition to National Standards as well (Buutveld, 2009).

These stances triggered a media response that was vociferous by New Zealand standards, being more comparable to the attacks on teachers in England during the 1980s than anything New Zealand had experienced previously. Daily newspaper editors and commentators across the country accused teachers of refusing to be accountable with little support for their concerns. ${ }^{9}$ While the arguments were often ill- 
informed (e.g., "Better to make it plain", 2009), they had the effect of removing any sense of public support for the concerns of teachers and principals. A fresh burst of media indignation in September surrounded the case of Paul Heffernan, a primary principal who had written a tongue-in-cheek account of how he would play to win under National Standards. ${ }^{10}$ Ironically, this had been done as part of a forum on a Ministry of Education website for education leaders after the forum was colonised by principals as a space to express their concerns about National Standards. Although the Dominion Post asked "Why has this public servant still got a job?' ('Listen and learn, teachers", 2009), Heffernan's blog can also be seen as a highly ethical act. It highlighted the risks of performativity and demonstrated the power of humour in communicating that risk.

With the support of the media apparently behind it, the Government pushed out the timeline for reporting National Standards data to 2012 but did not provide any assurances about taking steps to prevent the misuse of data. It also announced that advisory services for teaching the arts, science and physical education were to be withdrawn for 2010 in order to fund support for the introduction of National Standards. This provided an immediate, tangible example of the curriculum being narrowed and also emphasised that National Standards were being introduced frugally ${ }^{11}$ with an enormous assumption of goodwill on the part of primary teachers and principals.

National Standards were launched on 23 October, the day before Labour weekend.

While Prime Minister John Key called the plan "one of the most important steps" his Government would ever take (Dye, 2009), the NZEI and NZPF were conspicuous by their absence and the NZEI announced its intention to hold its own forum on the standards. PPTA also used the event to criticise National Standards ("National standards threaten NCEA", 2009). Media coverage of the event also saw the first editorial supporting teachers in their stance against National Standards ("Let teachers teach", 2009) and the following week a national lobby group called 'Parents against Labelling' had formed.

By the end of its first year, National Standards were the most obvious area of education where National looked most politically exposed by so little enthusiasm within the sector, growing public concern that the teachers might have a reason for their views, and a 
conservative but ever fickle media. National was attempting to persuade teachers and principals rather than risk serious confrontation with them. Its hand was unwittingly shown, for instance, in a communication proposal that accompanied its scrapped plan to lay off teachers which was released under the Official Information Act. This noted the risk that "In addition to potentially sending a negative message to the sector, reducing staffing may make the sector less willing to implement Government priorities, in particular the national standards" (Hartevelt, 2009c).

\section{Conclusion}

National's first year moved education policy in a clearly neo-liberal direction, with greater support for private schools and privatisation than in the previous decade and clearer indicators of 'quality' through the imposition of National Standards. It also saw the reinforcement of Te Kotahitanga as a suitable initiative to be supported by National despite being developed under Labour. Meanwhile some areas which might have been predicted to change, such as TFEA (decile funding), were left alone. ${ }^{12}$ A year after the election, school level education policy in New Zealand was already the most contested it had been for a decade. 2010 was to see further developments in some of the areas discussed. For example, in February the Inter-Party Working Group for School Choice recommended a partial voucher system (Inter-Party Working Group for School Choice, 2010) while a minority report simultaneously released by ACT predictably went further (Act Party, 2010). In July the government announced that tenders for public private partnerships to build schools could be called as early as 2011 (English \& Tolley, 2010). Throughout the year there was a continuing standoff over National Standards with varying opposition to the policy from the NZEI, New Zealand Principals' Federation and other groups and individuals but few concessions from Government.

If the contested ideology of neo-liberalism comes to further dominate New Zealand education policy in the next few years, research could have an important role to play in providing some light amidst the heat of reform. However, it needs to be recognised that much of the appeal of neo-liberal policy is populist rather than evidence-informed. Lubienski (2008) points out that although the body of academic research evidence does not support the growth of choice programmes in the USA, these continue to grow because 
choice has increasingly become an ideology supported by advocacy groups despite whatever the research 'says'. Burch (2009, p. 83) characterises ideology as being that "markets can succeed where government has failed and the role of policy is to cheerlead and stimulate demand." In this context the value of educational research may need to be constantly reasserted by New Zealand educators.

A related problem New Zealand faces is that our national capacity to undertake searching research into the impact of education policy is becoming quite limited. There are numerous reasons for this including the way most New Zealand education research is funded by the Ministry of Education rather than having more neutral research councils or bodies, ${ }^{13}$ and the business orientation of New Zealand universities increasingly precluding research which is not charged out at full overheads. Salaries for New Zealand academic posts are generally less competitive than those offered by universities overseas and they tend to involve relatively heavy teaching workloads. The way the Performance Based Research Fund requires so many 'outputs', different indicators of 'peer esteem' and 'contributions to the research environment' from New Zealand academics may also not be conducive to really in-depth research programmes.

In such a context it is becoming increasingly important to tap into academic analyses of neo-liberal policies in other national settings where research and scholarship is often better funded and more able to be searching than its New Zealand counterpart. For instance, Ball (2007) and Burch (2009) raise carefully researched concerns regarding the 'on the ground' effects of privatisation. Such work deserves careful consideration in the New Zealand/Aotearoa context. Similarly, writers such as Alexander (2009), Ball (2003), Gillborn \& Youdell (2000), Hursh (2008), Nichols \& Berliner (2007), Reay \& William (1999) and Stobart (2008) raise a variety of concerns about the effects of performativity on schools and students which are relevant to National Standards. While it is true that New Zealand is a distinctive arena for policy, there is a balance to be struck between acknowledging the importance of this distinctiveness and recognising the insights provided by good educational research and scholarship on offer elsewhere. New Zealand as a small nation is usually a 'borrower' rather than a 'lender' of education policy. It must be a (discriminating) borrower of the accompanying intellectual critiques as well. 


\section{References}

Act Party. (2010). Free to learn. Wellington: Author.

Alexander, R. (Ed.). (2009). Children, their world, their education: Final report and recommendations of the Cambridge Primary Review. London: Routledge.

Anger over National Standards consultation. (2009) NZEI media release, June 29.

Ball, S. (2003). The teacher's soul and the terrors of performativity. Journal of Educational Policy, 18(2), 215-228.

Ball, S. J. (1998). Big policies/small world: An introduction to international perspectives in education policy. Comparative Education, 34(2), 119-130.

Ball, S. J. (2007). Education PLC: Understanding private sector participation in public sector education. London: Routledge.

Beaumont, N. (2009, August 31). Threat to fudge exam results. The Dominion Post, Retrieved: http://www.stuff.co.nz/national/education/ 2816103/Threat-to-fudge-exam-results

Better to make it plain [Editorial]. (2009, July 8). The Dominion Post, p. B4.

Bishop, R., Berryman, M., Tiakiwai, S., \& Richardson, C. (2003). Te Kotahitanga: The experiences of year 9 and 10 Mãori students in mainstream classrooms: Report to the Ministry of Education. Wellington: Ministry of Education.

Bishop, R. (2005). Pathologising the lived experiences of the indigenous Māori people of Aotearoa, New Zealand. In C. Shields, R. Bishop \& \& A. Mazawi (Eds.), Pathologising practices: The impact of deficit thinking on education. New York: Peter Lang.

Black, J. (2008, November 8). The racial divide. New Zealand Listener November 8, p. 14.

Burch, P. (2009). Hidden markets: The new educational privatization. London: Routledge.

Buutveld, E. (2009, July). Generating futures. Presidential address to NZPF National Conference, Palmerston North.

Corporations running schools possible, says law expert. (2009). New Zealand Education Review, May 8, p. 3.

Courtney, B. (2009, October 20). Letter to editor. The Dominion Post.

Dye, S. (2009, October 24). "Signposts"-PM tells how it will work. The New Zealand Herald. Retrieved from http://www.nzherald.co.nz/nz/news/ article.cfm?c_id=1\&objectid $=10605129$

English, B., \& Tolley A. (2010, July, 21). School property PPP moves to next stage. New Zealand Government Press release. 
Gerritsen, J. (2008). Slim choice for voters. New Zealand Education Review, November 7, p. 1.

Gibson, A. (2009, September, 4). Dedicating private muscle to public need. New Zealand Herald.

Gillborn, D., \& Youdell, D. (2000). Rationing education: Policy, practice, reform, and equity. Buckingham: Open University Press.

Gordon, L. (2009a, August 31). Oh no! The nineties are back! New Zealand Education Review. August 31, pp. 6-7.

Gordon, L. (2009b, July 31). A worrying agenda. New Zealand Education Review, p. 7.

Government accused of robbing poor to pay rich. (2009). New Zealand Education Review, 5 June, p. 3.

Govt should not bail out private schools - union. (2009, February 17). National Business Review, February 17. Retrieved from http://www.nbr.co.nz/article/ govt-should-not-bail-out-privateschools-union-54603

Harris J. (2008a, December 12). Education Bill dead in water. New Zealand Education Review, p. 1.

Harris, J. (2008b, November 7). Independent schools unlikely to lower fees. New Zealand Education Review, p. 2.

Hartevelt, J. (2009a, August 8). 250 poor families offered private scholarships. The Press. Retrieved from http://www.stuff.co.nz/the-press/news/2731983/ 250-poorfamilies-offered-private-scholarships

Hartevelt, J. (2009b, October, 20). Critics raise spectre of bulk funding. The Press.

Hartevelt, J. (2009c, September, 30). Bid to shed 770 teachers axed. The Press. Retrieved from http://www.stuff.co.nz/national/education/2915362/Bid-toshed770-teachers-axed.

Hunt, T. (2009). Public good, private money. New Zealand Education Review. July 31 , pp. 8-9.

Hursh, D. (2008). High-stakes testing and the decline of teaching and learning. New York: Rowman \& Littlefield.

Inter-Party Working Group for School Choice. (2010). Step change: Success the only Option: Wellington: Author.

Key plans to boost private school funding. (2007, September, 29). The Press. Retrieved from http://www.stuff.co.nz/national/politics/33937

Laxon, A. (2009, August 15). Schools lose in Key plan for sport. The New Zealand Herald. Retrieved from http://www.nzherald.co.nz/nzgovernment/ news/article.cfm?c_id=144\&objectid $=10590950$ 
Let teachers teach, not count. (2009, October 25). Herald on Sunday.

Levin, B. (2001). Reforming education: From origins to outcomes. London: RoutledgeFalmer.

Lewis, J. (2009, September 18). Principals angry over scholarships. Otago Daily Times. Retrieved from http://www.odt.co.nz/news/dunedin/74486/principalsangryover-scholarships.

Listen and learn, teachers. (2009, September 2). The Dominion Post.

Lubienski, C. (2008). School choice research in the United States and why it doesn't matter: The evolving economy of knowledge production in a contested policy domain. In M. Forsey, G. Walford, \& S. Davies (Eds.), The globalization of school choice? (Oxford Studies in Comparative Education series.) (pp. 27-54). Oxford: Symposium Books.

Māori students at risk, say teachers. (2010, March, 26). New Zealand Herald.

Māori Party. (2008). Election policy. Retrieved October 15, 2010, from http://www.maoriMāoriparty.org/index.php?pag=cms\&id=130\&p=electionpolicy.html

Minister backs mother's stand on school donation. (2009, July 16). New Zealand Herald.

Minto, J. (2009a, June 2). Rich kids do better in the budget handout to public schools. The Press. Retrieved from http://www.stuff.co.nz/thepress/opinion/ columnists/2463677/Rich-kids-do-better-in-the-Budget-handout-to-public-schools

Minto, J. (2009b, April). Blurred lines and muddled thinking: School integration in 2009. Paper presented to the AGM of the Quality Public Education Coalition, Palmerston North.

Misa, T. (2009, July 6). League tables are an unhelpful sideshow, New Zealand Herald.

National Party \& ACT Party. (2008, 16 November ). National-ACT confidence and supply agreement. Retrieved from http://www.act.org.nz/

National standards threaten NCEA. (2009). PPTA media release, October 23.

Nichols, S. L., \& Berliner, D. (2007). Collateral damage: How high-stakes testing corrupts America's schools. Cambridge MA: Harvard Education Press.

Nuts and bolts missing from policy. (2008). New Zealand Education Review, November 7, p. 4.

Office of the Hon. Chris Carter. (2008). Key statistics: The government's investments in education 1999-2008. Wellington, NZ: Author.

Openshaw, R. (2007). Evaluation of Te Kotahitanga: Phase 3. Wellington: PPTA. 
Parents support National Standards. (2009). Press Release from Office of Minister of Education Anne Tolley, 20 September.

Pepperell, S. (2009, August 9). Private school rolls caned by recession. Sunday Star Times. p. A7.

Principle must triumph on school zoning. (2009, April, 9). New Zealand Herald. Editorial, p. 9.

Public private partnerships on fast track. (2009, August 28). The Main Report. Retrieved from http://www.themainreport.co.nz/home/free-articles/public private-partnerships-on-fast-track.html

Public-private infrastructure fund to invest up to $\$ 500 \mathrm{~m}$. (2009, July, 23). New Zealand Herald.

Reay, D., \& William, D. (1999). 'I'll be a nothing': Structure and agency and the construction of identity through assessment. British Educational Research Journal, 25(3), 343-354.

Roughan, J. (2009, April 11). Expel protectionism from schools. The New Zealand Herald. Retrieved from http://www.nzherald.co.nz/studentsstudy/news/ article.cfm?c_id $=329 \&$ objectid $=10566114$

Roy, H. (2009, March). Independent schools: Providing real choice in education. Speech to the Independent Schools of New Zealand's CEO Day, Wellington: Airport Conference Centre, Wellington.

Rudman, B. (2008, August 13). Tunnel vision over PPPs is wrong. New Zealand Herald.

Schagen, S., \& Hipkins, R. (2008). Curriculum changes, priorities, and issues: Findings from the NZCER secondary 2006 and primary 2007 national surveys. Wellington: NZCER.

Sharples, P. (2010). Key attributes of successful Kura Kaupapa Māori:. Speech to Te Rūnanganui o Ngā Kura Kaupapa Māori o Aotearoa, 5 October 2010.

Smith, A. B., \& Gaffney, M. (1997). Evaluation of the TIE project: A preliminary report. Dunedin: Children's Issues Centre, University of Otago.

Smith, J. (2009a, January 17). Private schools feeling the pinch Weekend Herald, p. A3.

Smith, J. (2009b, April 3). Top high schools seek zoning exemption. New Zealand Herald.

Smyth, J., \& McInerney, P. (2007). Teachers in the middle: Reclaiming the wasteland of the adolescent years of schooling. New York: Peter Lang.

Stobart, G. (2008). Testing times: The uses and abuses of assessment. London: Routledge.

Thomas, S. (2007). Roll play. Auckland: Maxim Institute. 
Thrupp, M. (1998). Exploring the politics of blame: School inspection and its contestation in New Zealand and England. Comparative Education, 34(2), 195-209.

Thrupp, M. (Ed.). (1999). A decade of reform in New Zealand education: Where to now? Hamilton: University of Waikato.

Thrupp, M., \& Hursh, D. (2006). The limits of managerialist school reform: The case of target-setting in England and the USA. In H. Lauder, P. Brown, J. Dillabough, \& A. H. Halsey (Eds.), Education, globalization, and social change. Oxford: Oxford University Press.

Thrupp, M., \& Irwin, R. (Eds.). (2010). Another decade of New Zealand education policy: Where to now? Hamilton: Wilf Malcolm Institute of Education Research.

Todd, R. (2009, October 2). Ngai Tahu eyed in bid to keep school from closing. The Press. Retrieved from http://www.stuff.co.nz/national/education/ 2923572/Ngai-Tahu-eyed-in-bid-to-keep-school-from-closing

Tolley, A. (2009). National administration guidelines: Amendments. New Zealand Parliamentary Debates, 653, 2704.

Trevett, C. (2007, October 1). Nats may let landlords own state school. New Zealand Herald.

Woulfe, C. (2009, November 1). "Three Rs" plan alarms parents. Sunday Star Times. Retrieved from http://www.stuff.co.nz/sunday-star-times/news/3019004/

Wylie, C., Hodgen, E., \& \& Darr, C. (2009). National standards consultation analysis. Wellington: NZCER.

\section{The author}

Martin Thrupp is Professor of Education at the University of Waikato. He has also held senior positions at King's College London and at the Institute of Education, University of London. His research interests involve the nature and impact of school-level education policy and the impact of diverse school contexts on school processes. He has published widely in these areas, focussing especially on schooling in New Zealand and England

Email: thrupp@waikato.ac.nz

\footnotetext{
This article is based on the concluding chapter of Thrupp \& Irwin (2020).

There was only a limited repudiation of the market which was offset by an increase in managerialism in some areas. Labour also created policies that would make it easy for National to move policy further to the Right once elected. For instance the Education Standards Bill (2001) offered the potential for greater performativity without much legislative change. Contestable funding could be easily withdrawn. Heavy emphasis on the quality of teaching set the scene for 'the politics of blame' (Thrupp, 1998) where governments attempt to construct student or institutional 'underperformance' or 'failure' as the clear responsibility of schools and teachers. In short, the education policy legacy National was left with would require only incremental change to fit a more neo-liberal agenda.
} 
3 E.g., "The public needs to be provided with better information on school performance, including Māori and Pacific achievement" (Māori Party, 2008).

4 Integrated schools also came under further public scrutiny later in the year when Rathkeale College suggested a parent mortgage her home in order to pay a large school 'donation' when she insisted she couldn't pay. The subsequent debate over whether the school was being heavy-handed or the parent irresponsible ended in the Minister ordering an inquiry and confirming that parents could not be required to pay voluntary donations. ("Minister backs mother's stand", 2009)

5 For instance Openshaw (2007) notes that it was claimed in a 20/20 documentary screened on TV3 on 23 April 2007 that Te Kotahitanga was on its way to solving the problem of Māori underachievement, and in less than a generation. There was also an earlier claim that " $[t]$ he results of this study show that it is feasible within a relatively short period of time, to improve Māori students' educational achievement. The results add to both local and international literature that shows that changing how teachers theorise their relationships with Māori students and how they interact with them in the classroom can have a major impact upon Māori students' engagement with learning and short term achievement" (Bishop et al., 2003 p. 198).

6 Comment made on Radio New Zealand 'Insight' programme on National Standards, Sunday 26 April 2008.

7 This is the first point of Te Kotahitanga's 'Effective Teaching Profile' (Bishop et al., 2003, p. 95).

8 Letter to Dominion Post editor from Bill Courtney, Chairperson, Khandallah School Board of Trustees, 20 October 2009. Tolley would later say about parents: "I don't think they were ever asked, put up a show of hands, do you want this or not... We sort of did that at the election. It was a key part of our manifesto, so we do have a public mandate" (cited in Woulfe, 2009).

9 Misa (2009) provided a rare exception.

10 Heffernan wrote in his blog "Awesome, awesome, awesome - by crickey we are going to teach to the easiest test we can find. We are going to reteach and reteach baby. We will even fudge the results big time. My school is going to be top school on the league table so that my community will know I run a brilliant school - an outstanding principal - parents will flock to my door. To hell with anything creative. Hmmm I will have to toss out Inquiry learning as well as I will not have any time - it's all literacy and numeracy test preparation time now. Hmmm, perhaps I need a further run through /practice of the test. And don't say that this will not happen - it sure did with NCEA. League Tables will be here to stay. At the consultation meeting in Auckland it was commented by the presenters that yes indeed the media would have access to the results - can't stop them. Hell, test results have to be in soon - better have another run through. But wait maybe, maybe if my results are a tad below expected they will give me some more funding. Way below, more funds yippy do, and that new zappy do computer link up with Uranus will be a goer!!!!”

11 The budget allocated $\$ 36$ million over 4 years for this nation-wide reform.

12 One exception was that annual grant for secondary school sports would be withdrawn and allocated on a non-decile basis, such that low decile schools would lose funds while wealthier schools gain (Laxon, 2009).

13 The Marsden fund is one exception but funds only a small percentage of New Zealand's educational research. 